\title{
Assessment of Farmers' Indigenous Technology Adoptions for Climate Change Adaptation in Nigeria
}

\author{
Idowu Ologeh, Francis Adesina, and Victor Sobanke
}

\section{Contents}

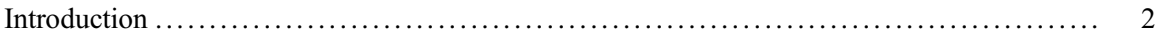

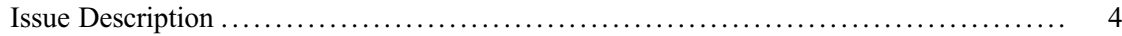

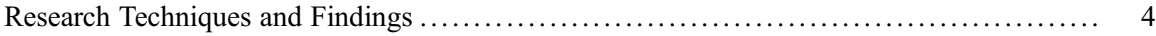

Devastating Effects of Climate Change on Smallholder Farmers ................... 6

Indigenous Adaptation Techniques in Use in Nigeria ........................... 6

Constraints to the Development of Indigenous Adaptation Techniques in Nigeria ....... 10

Indigenous Adaptation Techniques Contributing Factors .......................... 10

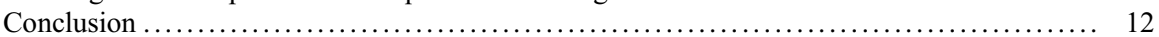

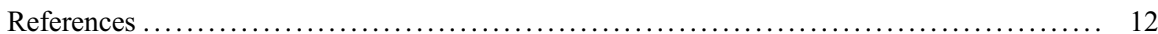

\section{Abstract}

Agriculture has shown a considerable capacity to adapt to climate change. Many adaptations occur autonomously without the need for conscious response by farmers and agricultural planners. However, it is likely that the rate and magnitude of climate change may exceed that of normal change in agriculture that specific technologies and management styles may need to be adopted to avoid the

This chapter was previously published non-open access with exclusive rights reserved by the Publisher. It has been changed retrospectively to open access under a CC BY 4.0 license and the copyright holder is "The Author(s)". For further details, please see the license information at the end of the chapter.

I. Ologeh $(\bowtie)$

Department of Environmental Management and Toxicology, Lead City University, Ibadan, Nigeria e-mail: Ologeh.idowu@lcu.edu.ng

F. Adesina

Department of Geography, Obafemi Awolowo University, Ile-Ife, Nigeria

V. Sobanke

Research and Planning Department, National Centre for Technology Management, South West Office, Lagos, Nigeria 
most serious of effects. Thus areas likely to be most vulnerable to climate variability can be spared from its impacts through implementation of appropriate adaptation measures such as development of indigenous technologies.

Six hundred farmers from the six geopolitical zones of Nigeria were surveyed and they all possess different indigenous adaptation strategies ranging from swamp farming (Oyo State), application of neem seed (Kaduna State), soil erosion control (Enugu State), rainwater harvesting (Taraba State), land improvement (Cross River State) to farmland management (Benue State). They all have simple but profound technologies driving these schemes with much success. These indigenous adaptation techniques are majorly constrained by inadequate financial resources. Indigenous technology adoption is affordable with high revenue potential.

\section{Keywords}

Indigenous technology $\cdot$ Climate change adaptation $\cdot$ Farmers $\cdot$ Nigeria

\section{Introduction}

Historically, agriculture has shown a considerable capacity to adapt to changing climatic conditions. If climate change is gradual, the adaptation may go widely unobserved and the adjustment process largely independent (Parry et al. 2004). In the field of climate change, vulnerability has been described as the degree to which a system is susceptible to, or unable to cope with, adverse effects of climate change, including climate variability and extremes (Marrewijk 2011). Thus the need for climate change adaptation/mitigation measures to combat vulnerability. The major task of climate change adaptation and mitigation in agriculture is to produce more food efficiently and with clear reductions in greenhouse gas (GHG) releases from food manufacturing and marketing. "Adaptation" can be defined as societal or ecosystems efforts to prepare for or cope with future climate change. The coping methods can be defensive (i.e., being protective against adverse impacts of climate change), or adaptable (i.e., seizing the benefits of any advantageous effects of climate change) (USEPA 2014).

Nigeria along with other developing countries under UNFCCC is to focus on adaptation to make them able to cope with the new extremes in climatic regimes; they are also to concentrate on environmentally and economically sustainable development (Adesina and Odekunle 2011a). The argument is, the developing countries' growth is being impaired by climate change effect and these countries produce only a small fraction of the GHG that is causing climate change. They also have fragile adaptive capability because their economies are still growing, thus they are highly vulnerable to the impacts of climate change.

Climate change adaptation is not novel; history has told how human societies whether by migration, improved crop varieties, or diversifying housing types have repeatedly proven strong capacities for adapting to different climates and environmental changes (Adger et al. 2007). However, the current rate of global climate change is unusually high compared to past changes that society has experienced and 
thus new innovations are necessary to combat the challenge. In this era that the world is getting increasingly interdependent, adverse effects of climate change on one community or economic sector can have aftermaths around the world (United States Global Change Research Programme - USGCRP 2009).

Adaptation is globally important because climate change will not become history soon. Many greenhouse gases linger in the atmosphere for 100 years or more after their emission and because of their long-lasting effects, they will continue to warm Earth in the twenty-first century, even if additional greenhouse gases emission were to stop today. Therefore, steps must be taken now to prepare for, and respond to, the impacts of climate change that are already occurring, and those that are projected to occur in the years ahead (USCGRP 2009).

There is need for continuous actions to mitigate climate because there are limits to the ability to adapt. Adaptation alone on long-term basis may not be sufficient to cope with all the projected impacts of climate change, thus it will need to be continuously coupled with actions to lower greenhouse gas emissions (IPCC 2007).

Adaptation is based on the level of socioeconomic development of a country; the resilience and adaptive capacity of a country is dependent on its level of development with respect to economy and political stability. To improve adaptation strategies, a clear understanding of local susceptibilities to climate change and critical thresholds must be established. Adaptation strategies should be adequately flexible in order to accommodate future possible changes in climatic parameters which may be responsible for quick review of plans; the plan should be reviewed periodically.

A myriad of possible adaptation strategies for agriculture are available; some of the most prominent in Nigeria are innovative indigenous technology options ranging from improved crop varieties, composting of organic waste, recycling and waste minimization, improved cultivation techniques, and cover cropping (Eze and Osahon 2015).

Reactive adaptations are those which occur after the impacts of climate change have been experienced, while anticipatory adaptations are proactive, undertaken before the impacts are fully felt. Planned adaptations are generally anticipatory, but can also be reactive (i.e., climate change effects are experienced). Farmers have access to various adaptations depending on their local environments and the specific farming system.

Some impact studies have suggested "adaptations" involving reductions and expansions of agricultural zones. This implies that some farmers would relocate, or others would completely change their type of farming while others would stop operations in some locations. Also, in other locations, there would be new farmers and some existing landowners would try new types of farming (Adesina and Odekunle 2011b). Although adaptations can be strategic at the farm level, the term "planned adaptation" is commonly used to describe actions taken by governments as a conscious policy response. Probable governments' planned adaptations include reinforcement of technological adaptations, such as crop development and early warning systems, promotion of land and water use options, changes in diversification or intensity of production aid, transformed financial support in established programs, and impromptu compensation. 


\section{Issue Description}

Smallholder farmers were facing a lot of climate change-induced challenges on their farms of which flooding, pest and disease invasion, high temperature, and low crop yield are the most prominent. The Nigerian government has promoted various adaptation measures as its effort to curtail these challenges. These include provision of improved crop varieties, fertilizers, irrigation schemes, and geodata (Adefolalu 2007). Wisner et al. (2004) report that farmers' vulnerability is not determined by the nature and magnitude of climate change as such, but by the interplay of the societal capacity to adapt and/or recuperate from environmental change. The adaptation capacity and degree of exposure is connected to environmental changes and also to changes in societal aspects such as land use and cultural practices. Most studies on climate change and agriculture in Africa have concentrated on actual and projected impacts as well as farmers' coping/adaptation strategies (Adejuwon 2004). There has been little or no work in the area of local/indigenous adaptation technologies and their challenges or success. This chapter will therefore attempt, through a questionnaire survey, Focus Group Discussions, and review of relevant literature, to fill this gap.

The objective of this chapter is to assess indigenous technology adaptation options being used by smallholder farmers in Nigeria.

\section{Research Techniques and Findings}

The survey area is Nigeria; for ease of data collection, the major food-producing state of each geopolitical zone in the country is sampled for the survey. After relevant literature and National Bureau of Statistics consultation, the following six states were selected for the survey:

North-Central Zone - Benue State

North East Zone - Kaduna State

North-West Zone - Taraba State

South-East Zone - Enugu State

South-South Zone - Cross River

South-West Zone - Oyo State

It is very important to assess the various indigenous technology adaptations in use by smallholder farmers in Nigeria so as to know which can be fully developed for national adoption. To achieve this objective, 600 questionnaires were administered to smallholder farmers in the six states to survey their various indigenously designed adaptation options to climate change. The questionnaires were designed to collect information on farmers' biometric data, years of experience and skills, farm size, types of crops cultivated, educational level, experiences on climate change effects, and indigenous adaptation techniques. Secondary data was obtained from NBS and the Agricultural Development Agencies of each of the States. The retrieved 
Table 1 Socioeconomic characteristics of sampled smallholder farmers

\begin{tabular}{|c|c|c|c|c|c|c|c|}
\hline Variables & Categories & Benue & Cross River & Enugu & Kaduna & Oyo & Taraba \\
\hline & & Freq $/ \%$ & Freq $/ \%$ & Freq $/ \%$ & Freq/\% & Freq $/ \%$ & Freq $/ \%$ \\
\hline Sex & $\begin{array}{l}\text { Male } \\
\text { Female }\end{array}$ & $\begin{array}{l}67 \\
33\end{array}$ & $\begin{array}{l}41 \\
59\end{array}$ & $\begin{array}{l}46 \\
54\end{array}$ & $\begin{array}{l}72 \\
28\end{array}$ & $\begin{array}{l}52 \\
48\end{array}$ & $\begin{array}{l}66 \\
34 \\
\end{array}$ \\
\hline \multirow[t]{4}{*}{ Age(years) } & $\leq 40$ & 2 & 3 & 0 & 1 & 0 & 4 \\
\hline & $41-50$ & 39 & 37 & 30 & 26 & 29 & 29 \\
\hline & $51-60$ & 54 & 51 & 59 & 58 & 61 & 59 \\
\hline & $61-70$ & 5 & 9 & 11 & 15 & 10 & 8 \\
\hline Marital & Single & 3 & 2 & 4 & 0 & 7 & 0 \\
\hline \multirow[t]{2}{*}{ Status } & Married & 97 & 96 & 91 & 99 & 89 & 98 \\
\hline & Widowed & 0 & 2 & 5 & 1 & 4 & 2 \\
\hline Levels of & Informal & 61 & 14 & 17 & 48 & 12 & 68 \\
\hline Educational & Primary & 32 & 52 & 32 & 38 & 23 & 30 \\
\hline Attainment & Secondary & 07 & 34 & 51 & 14 & 65 & 02 \\
\hline Farm & $\leq 1$ & 25 & 63 & 67 & 31 & 33 & 21 \\
\hline \multirow[t]{2}{*}{ Size(ha) } & $2-5$ & 57 & 26 & 29 & 42 & 55 & 56 \\
\hline & Above 5 & 18 & 11 & 4 & 27 & 12 & 23 \\
\hline Farming & $\leq 30$ & 13 & 19 & 18 & 11 & 17 & 6 \\
\hline Experience & $31-40$ & 60 & 55 & 53 & 58 & 56 & 62 \\
\hline (years) & Above 41 & 27 & 26 & 29 & 31 & 27 & 32 \\
\hline
\end{tabular}

Source: Fieldwork

questionnaires were imputed and analyzed using Microsoft Excel spreadsheet 2016 and the results are presented in frequencies and percentages.

A total of six hundred questionnaires were administered to smallholder farmers in the six states, and all were retrieved through the assistance of agricultural extension workers who administered them, the results are presented in Table 1.

In order to obtain realistic data, matured farmers are targeted, the average age is 53 years old. Majority $(86 \%)$ of the farmers have more than 30 years of experience in farming with $60 \%$ of them owning more than one hectares of land. Female farm owners (42\%) are mostly found in Southern Nigeria while men majorly own farmland in the north, and employ numerous women laborers. The most grown crops across Nigeria as detected in the data are cassava, maize, yam, rice, and vegetables.

Almost all the farmers (97\%) complained of the various losses they have incurred due to devastation effects of climate change ranging from drought encroachment in the north to flooding in the south. The totality of the respondent farmers have poor knowledge of the scientific explanations behind climate change, but experience taught them that nature (weather) is no longer their friend and they have to devise strategies to make it work in their favor. Their understanding is that nature (or the gods) is fighting them through the massive attack of pests and diseases, flooding, erratic rainfall, high temperature, and low yield. As a result, they devise different techniques to adapt to climate change effects including sacrificing to the gods. These indigenous adaptation techniques vary from zone to zone, depending on the 
prevalent climate change effect in the area. Swamp farming was devised in Oyo State, discovery, and application of neem seed to enhance soil fertility in Kaduna State, improved soil erosion control in Enugu State, rainwater harvesting in Taraba State, intentional cover cropping in Cross River State to farmland management (organic manure) in Benue State. They all have simple but profound technologies driving these schemes which will be discussed in details.

This finding harmonized with that of Eze and Osahon (2015) who listed adaptation strategies as improved crop varieties, composting of organic waste, recycling, and waste minimization, improved cultivation techniques, and cover cropping.

\section{Devastating Effects of Climate Change on Smallholder Farmers}

All the smallholder farmers surveyed have in their more than 30 years of experience suffered different adverse effects of climate change. The prominent effect in Northern Nigeria is erratic rainfall and unusual heat (heatwave). They are also faced with desert encroachment advancing into Nigeria from Niger republic and pest invasion. Their counterparts in the South are majorly faced with flooding, infertility, increase in temperature, and pest invasion. The major effect in North Central is the increase in temperature, soil infertility, and pest invasion.

The finding is in agreement with the work of Lybbert and Sumner (2010) that temperature increase is an indication of climate change, and also the work of Adegoke et al. (2014), who stated that weeds, pests, and fungi thrive under warmer temperatures, wetter climates, and increased carbon dioxide $\left(\mathrm{CO}_{2}\right)$ levels.

The different climate change effects being experienced in different zones in Nigeria dictate the corresponding indigenous adaptation techniques, and these are presented in Tables 2 and 3.

\section{Indigenous Adaptation Techniques in Use in Nigeria}

\section{North-Central Zone - Benue State}

Benue State is the food basket of Nigeria, the state is popular for large-scale food and fruit production including yam, cassava, sweet potato, beans, maize, millet, guinea corn, vegetables, soybeans, rice, and citrus. The smallholder farmers in Benue State are faced with climate change impacts such as soil infertility, increase in temperature, pests and diseases invasion, crop failure, and increased weed. To mitigate/adapt to these effects, the adaptation strategies common to smallholder farmers in the state are mixed cropping, growing pest/disease-resistant crop varieties, use of cover crops, and making bigger ridges.

The prominent indigenous adaptation practice in the state is local farmland management. The Benue farmers devised a farmland management practice to adapt to climate change. The practice entails conscious efforts to reduce temperature on farmlands and is very similar to organic agriculture. It is a complete management system with high organic matter content (mulching), soil cover (cover crops/tree 
Table 2 Devastating effects of climate change on smallholder farmers

\begin{tabular}{l|l|l|l|l|l|l}
\hline Variables & Benue & $\begin{array}{l}\text { Cross } \\
\text { river }\end{array}$ & Enugu & Kaduna & Oyo & Taraba \\
\hline Mean max 5 & $\begin{array}{l}\text { Mean } \\
\text { (M) }\end{array}$ & $\begin{array}{l}\text { Mean } \\
\text { (M) }\end{array}$ & $\begin{array}{l}\text { Mean } \\
\text { (M) }\end{array}$ & $\begin{array}{l}\text { Mean } \\
\text { (M) }\end{array}$ & $\begin{array}{l}\text { Mean } \\
(\mathrm{M})\end{array}$ & $\begin{array}{l}\text { Mean } \\
\text { (M) }\end{array}$ \\
\hline Soil infertility & 4.2 & 2.1 & 1.9 & 4.4 & 2.7 & 3.0 \\
\hline $\begin{array}{l}\text { Increase in } \\
\text { temperature }\end{array}$ & 4.3 & 4.0 & 4.3 & 4.2 & 4.4 & 4.1 \\
\hline Pest invasion & 4.6 & 4.7 & 4.5 & 4.4 & 4.5 & 4.4 \\
\hline Crop failure & 3.6 & 4.2 & 3.9 & 4.0 & 3.5 & 3.7 \\
\hline Increased weed & 3.9 & 3.8 & 3.1 & 2.8 & 3.4 & 4.2 \\
\hline Drought & 1.2 & 0.8 & 1.5 & 3.8 & 1.1 & 3.7 \\
\hline Land degradation & 2.3 & 2.8 & 2.5 & 3.6 & 3.1 & 3.2 \\
\hline Flooding & 3.2 & 3.8 & 4.1 & 3.6 & 3.9 & 2.9 \\
\hline Access to water & 2.4 & 0.5 & 1.5 & 3.7 & 1.2 & 3.4 \\
\hline $\begin{array}{l}\text { Decrease in soil } \\
\text { moisture }\end{array}$ & 3.1 & 1.5 & 2.4 & 3.2 & 2.1 & 3.7 \\
\hline Erosion & 3.4 & 3.2 & 3.9 & 3.1 & 3.8 & 2.9 \\
\hline Source: & & & & & &
\end{tabular}

Source: Fieldwork

planting), and high soil fertility (crop rotation, organic manures, and legume planting) thus retaining nutrient and water, building more floods, drought, and land degradation resilient soils.

\section{North West Zone - Kaduna State}

Kaduna is a state in which $80 \%$ of the people are actively engaged in farming. They produce crops ranging from yam, maize, beans, guinea corn, millet, rice, and cassava. The prevalent climate change impacts in the state are drought, pests and diseases invasion, crop failure, land degradation, increase in temperature, flooding, access to water and soil infertility. The widely adopted adaptation practices are mixed farming, mixed cropping, growing drought-resistant crop varieties, growing pest-resistant crop varieties, crop rotation, irrigation, roof water harvesting, and making bigger ridges.

The unique indigenous adaptation method in use in the State is the application of neem seed for pest control (used as fumigant, pesticide), compost (used as fertilizer, manure), and soil fertility (used as soil conditioner and urea coating agent).

\section{North-East Zone - Taraba State}

Taraba State just as his North-West counterpart is $80 \%$ agrarian. They produce crops ranging from maize, millet, sorghum, rice, yam, cassava, and sweet potatoes. They experience climate change effects such as high rate of weeds, drought, decrease in soil moisture, increase in temperature, decrease in crop yields, and high rate of pests and disease incidence. The adaptation measures generally in use in the State are growing drought-resistant crop varieties, crop rotation, irrigation, integration of livestock farming system, changing crop varieties, mulching, and intercropping. 
Table 3 General adaptation techniques in use in Nigeria

\begin{tabular}{|c|c|c|c|c|c|c|}
\hline Variables & Benue & $\begin{array}{l}\text { Cross } \\
\text { river }\end{array}$ & Enugu & Kaduna & Oyo & Taraba \\
\hline Mean max 5 & $\begin{array}{l}\text { Mean } \\
(\mathrm{M})\end{array}$ & $\begin{array}{l}\text { Mean } \\
(\mathrm{M})\end{array}$ & $\begin{array}{l}\text { Mean } \\
(\mathrm{M})\end{array}$ & $\begin{array}{l}\text { Mean } \\
(\mathrm{M})\end{array}$ & $\begin{array}{l}\text { Mean } \\
(\mathrm{M})\end{array}$ & $\begin{array}{l}\text { Mean } \\
(\mathrm{M})\end{array}$ \\
\hline Mixed cropping & 3.7 & & & 3.8 & & \\
\hline $\begin{array}{l}\text { Growing pest/disease resistant } \\
\text { crop varieties }\end{array}$ & 3.9 & 3.7 & 3.7 & 4.1 & 4.4 & 3.4 \\
\hline Use of cover crops & 3.6 & 3.7 & 2.9 & 3.3 & 3.4 & 3.1 \\
\hline Making bigger ridges & 3.5 & 3.3 & 3.3 & 3.7 & 3.4 & 3.3 \\
\hline Mixed farming & 3.2 & 2.7 & 2.8 & 4.4 & 3.1 & 3.4 \\
\hline $\begin{array}{l}\text { Growing drought resistant crop } \\
\text { varieties }\end{array}$ & 3.1 & 2.1 & 2.8 & 3.6 & 2.8 & 3.5 \\
\hline Mulching & 3.1 & 4.2 & 3.3 & 3.2 & 3.9 & 4.4 \\
\hline Crop rotation & 3.4 & 2.1 & 2.4 & 3.7 & 2.7 & 4.1 \\
\hline Irrigation & 3.4 & 3.3 & 3.4 & 4.0 & 4.2 & 4.1 \\
\hline Roof water harvesting & 3.1 & 2.7 & 2.8 & 3.7 & 2.5 & 3.1 \\
\hline $\begin{array}{l}\text { Integration of livestock farming } \\
\text { system }\end{array}$ & 2.3 & 1.2 & 1.8 & 3.3 & 2.9 & 3.6 \\
\hline Changing crop varieties & 2.6 & 2.2 & 2.4 & 3.1 & 3.3 & 3.6 \\
\hline Intercropping & 3.2 & 2.3 & 2.8 & 3.1 & 3.3 & 3.8 \\
\hline Use of pesticides/herbicides & 2.4 & 2.5 & 3.9 & 2.7 & 4.2 & 3.1 \\
\hline $\begin{array}{l}\text { Construction of drainage } \\
\text { systems }\end{array}$ & 1.2 & 3.7 & 4.2 & 2.2 & 2.9 & 2.8 \\
\hline Contour cropping & 2.1 & 2.0 & 3.9 & 3.1 & 3.4 & 3.1 \\
\hline Diversification in crop planting & 2.4 & 3.6 & 3.8 & 2.8 & 3.2 & 3.0 \\
\hline Ridge construction & 2.8 & 2.7 & 3.3 & 3.4 & 3.3 & 3.5 \\
\hline Crop substitution & 3.4 & 2.1 & 2.8 & 3.3 & 3.4 & 3.7 \\
\hline Changing planting dates & 3.1 & 3.1 & 3.0 & 3.3 & 3.2 & 3.5 \\
\hline
\end{tabular}

Source: Fieldwork

The indigenous adaptation practice unique to Taraba State is rain harvesting. Access to water is an issue in the state and thus the need for irrigation. Rain harvesting is used to augment the water used for irrigation. The most common is roof water harvesting which is channeled into catchment tanks or concrete reservoirs.

\section{South-East Zone - Enugu State}

Enugu State has a diversified economy dominated by agriculture. Major crops produced in the State are yam, cassava, maize, rice, cowpea, sweet potatoes, and plantain. Their crop production is impaired by climate change effects such as increase in temperature, flood, soil erosion, pests and diseases invasion, and crop failure. Adaptation practices widely in use in the State include planting pest/diseaseresistant crop varieties, use of pesticides/herbicides, construction of drainage systems, contour cropping, and diversification in crop planting. 
Soil erosion is the major problem affecting smallholder farmers in Enugu State, and its volume was aggravated by the effects of climate change. Their key indigenous adaptation strategy is soil erosion control using stone and sandbags to divert erosion away from the farms, ridging, and use of wrapped weeds or grasses to cover planted heaps. Stems from previous harvests are also arranged or scattered on the soil in bands to reduce soil erosion. Tree planting on the borders of the farm also prevents soil erosion as the trees shield the farm from direct impact of rainfall.

\section{South-South Zone - Cross River}

Cross River State famously known for tourism and fishing is also fully involved in agriculture. The crops mainly cultivated in the State are cassava, yam, plantain, rice, and maize. Although it is a coastal state, they also have their share of climate change effects. They are affected by increased weeds, pests and diseases invasion, increase in temperature, crop failure, and flooding. They adapt by planting pest-resistant crop varieties, diversification of crops, planting cover crops, mulching, and construction of drainage systems.

Indigenous land improvement methods are the key indigenous adaptation practice in Cross River State. These methods include organic addition to the land (mulching, compost, and manure), cover tree planting, planting of legume crops (mixed cropping), and polyculture. Water harvesting from runoffs also helps to maintain soil moisture during dry season.

\section{South-West Zone - Oyo State}

Oyo State is an industrialized state with many educational institutions. It also enjoys diversified economy with agriculture as the major occupation. Smallholder farmers in Oyo State are faced with climate change effects like their counterparts in other states, this includes flooding, pests and diseases invasion, soil erosion, crop failure, and increased temperature. Their general adaptation methods are ridge construction, use of pesticides and pest-resistant crop variety, irrigation, crop substitution, and changing planting dates.

The major captivating indigenous adaptation method practiced by the smallholder farmers in Oyo State is swamp farming. There are lots of swamp areas in Oyo State, where smallholders resort to when there is prolonged delay in rainfall season. This initiative allows early and late farming as there is constant access to water. Some farmers in Oke Ogun area of the state channel their domestic wastewater to wet their vegetable farms all year round.

These findings are in agreement with that of Adger et al. (2007) that listed adaptation strategies as migration, improved crop varieties, or building different types of shelter, while Anríquez and Stamoulis (2007) list include changing the timing of operations, adoption of conservation tillage practices, and diversification in production systems, improvement of irrigation schemes, modification of farm support programs, and development of new plant varieties. 


\section{Constraints to the Development of Indigenous Adaptation Techniques in Nigeria}

The various indigenous adaptation strategies assessed have developmental constraints. The major is inadequate financial resources; adaptation practices are costintensive and these smallholder farmers cannot afford elaborate adaptation strategies. Even the indigenous methods need funding to develop, e.g., the planting and processing of neem seed in Kaduna State and soil erosion control in Enugu State. Other constraints include inadequate farm labor due to express increase in ruralurban migration; poor extension services, insufficient drought-resistant varieties, and strict adherence to local varieties (see Table 4).

\section{Indigenous Adaptation Techniques Contributing Factors}

The results of the partial least squares (Ringle et al. 2005) are presented in Fig. 1, and showed the factor loadings for all observed variables, $\mathrm{R}^{2}$ value of the unobserved

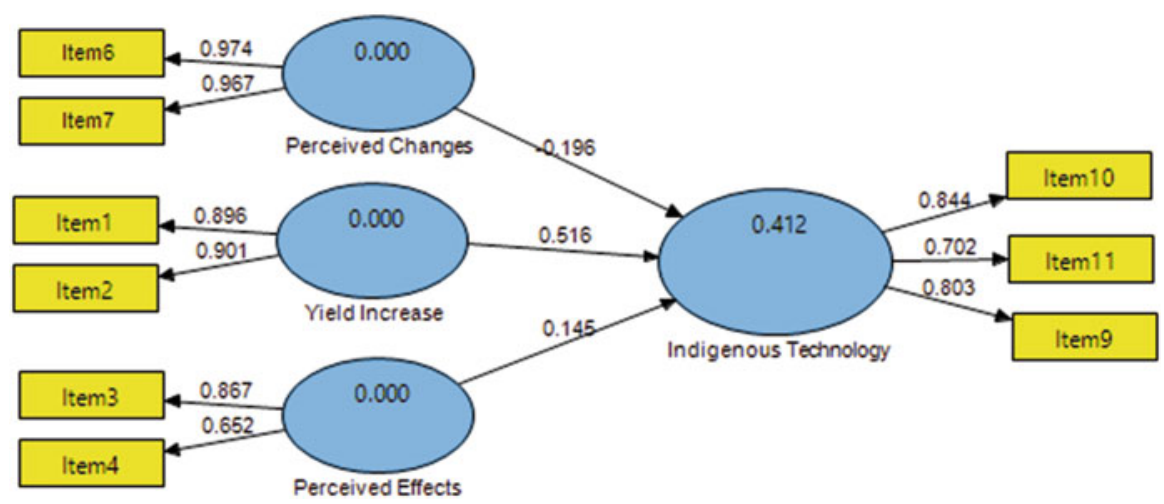

Fig. 1 Structural model of indigenous technology adoption

Table 4 Constraints to the development of indigenous adaptation techniques in Nigeria

\begin{tabular}{l|l|l|l|l|l|l}
\hline & Benue & $\begin{array}{l}\text { Cross } \\
\text { river }\end{array}$ & Enugu & Kaduna & Oyo & Taraba \\
\hline & $\begin{array}{l}\text { Freq } \\
/ \%\end{array}$ & $\begin{array}{l}\text { Freq } \\
/ \%\end{array}$ & $\begin{array}{l}\text { Freq } \\
/ \%\end{array}$ & $\begin{array}{l}\text { Freq } \\
/ \%\end{array}$ & $\begin{array}{l}\text { Freq } \\
/ \%\end{array}$ & $\begin{array}{l}\text { Freq } \\
/ \%\end{array}$ \\
\hline Finance & 93 & 92 & 88 & 95 & 91 & 86 \\
\hline Farm labor & 34 & 62 & 57 & 37 & 48 & 33 \\
\hline Poor extension services & 23 & 42 & 38 & 31 & 54 & 48 \\
\hline $\begin{array}{l}\text { Insufficient drought-resistant } \\
\text { varieties }\end{array}$ & 76 & 84 & 63 & 67 & 66 & 52 \\
\hline Strict adherence to local varieties & 62 & 33 & 28 & 56 & 14 & 51 \\
\hline
\end{tabular}

Source: Fieldwork 
Table 5 Reliability and validity of unobserved variables

\begin{tabular}{l|l|l|l|l|l}
\hline & AVE & $\begin{array}{l}\text { Composite } \\
\text { reliability }\end{array}$ & $\begin{array}{l}\text { Cronbach's } \\
\text { alpha }\end{array}$ & Communality & Redundancy \\
\hline $\begin{array}{l}\text { Indigenous } \\
\text { technology }\end{array}$ & 0.617 & 0.828 & 0.700 & 0.617 & 0.056 \\
\hline $\begin{array}{l}\text { Perceived } \\
\text { changes }\end{array}$ & 0.942 & 0.970 & 0.938 & 0.942 & \\
\hline Perceived effects & 0.589 & 0.737 & 0.317 & 0.589 & \\
\hline Yield increase & 0.807 & 0.893 & 0.761 & 0.807 & \\
\hline
\end{tabular}

Table 6 Path analysis

\begin{tabular}{l|l|l|l|l|l}
\hline & $\begin{array}{l}\text { Original } \\
\text { sample } \\
(\mathrm{O})\end{array}$ & $\begin{array}{l}\text { Sample } \\
\text { mean } \\
(\mathrm{M})\end{array}$ & $\begin{array}{l}\text { Standard } \\
\text { deviation } \\
(\mathrm{STDEV})\end{array}$ & $\begin{array}{l}\text { Standard } \\
\text { error } \\
(\mathrm{STERR})\end{array}$ & $\begin{array}{l}\text { T-statistics } \\
(\mid \mathrm{O} / \\
\text { STERR } \mid)\end{array}$ \\
\hline $\begin{array}{l}\text { Perceived changes - } \\
\text { > indigenous } \\
\text { technology }\end{array}$ & -0.196 & -0.198 & 0.072 & 0.072 & 2.703 \\
\hline $\begin{array}{l}\text { Perceived effects - } \\
\begin{array}{l}>\text { indigenous } \\
\text { technology }\end{array}\end{array}$ & 0.145 & 0.156 & 0.081 & 0.081 & 1.782 \\
\hline $\begin{array}{l}\text { Yield increase - } \\
\text { indigenous } \\
\text { technology }\end{array}$ & 0.516 & 0.519 & 0.077 & 0.077 & 6.665 \\
\hline
\end{tabular}

endogenous (dependent) variable as well as regression coefficients between exogenous and endogenous unobserved variables. Nine (9) observed variables with high loadings were retained for further analysis, while items with low factor loadings were removed. The $\mathrm{R}^{2}$ value of 0.412 indicates that about $41 \%$ variance observed in the choice of indigenous adaptation techniques employed by farmers can be explained by farmers' perceived effect of climate change, need for crop yield increase, and perception of changing weather.

Reliability and validity of unobserved variables is presented in Table 5. The results show that composite reliability $(\mathrm{CR})$ which indicates the convergent validity in all the constructs is adequate and above 0.7 the minimum threshold (Hair et al. 2010). The average variance extracted (AVE) which is a more conservative method of measuring convergent validity than CR (Malhotra and Dash 2011) is also within the recommended threshold $(>0.5)$. On the contrary, only the value of Cronbach's alpha for perceived effects was below the recommended threshold (0.7).

The results of the T-statistics showing the significant level of regression coefficients are presented in Table 6 . This result showed that indigenous adaptation techniques by respondents is influenced by their perceived changes $(2.703 ; p<0.05)$ and yield increase $(6.665 ; p<0.05)$. The result suggest that respondent's choice of indigenous adaptation techniques depends on the aspect of perceived changes in climatic parameters as well as the usefulness of climatic information. 


\section{Conclusion}

The chapter examined the various climate change effects affecting smallholder farmers across Nigeria. The general adaptation techniques adopted in each geopolitical zone of the nation were assessed as well as peculiar indigenous adaptation techniques initiated and in use in each zone. The constraints to the development of the indigenous adaptation techniques were also investigated. Going forward, these indigenous techniques need to be developed and commercialized; the state and federal government agricultural schemes and agencies can fund this project and support the efforts of the smallholder farmers. It is also essential for a functional link to be established between the farmers' indigenous innovation and the academia to foster research and development.

\section{References}

Adefolalu DO (2007) Climate change and economic sustainability in Nigeria. In: Paper presented at the international conference on climate change and economic sustainability held at Nnamdi Azikiwe University, Awka, Nigeria. 12-14 June 2007

Adegoke J, Araba A, Ibe C (2014) National agricultural resilience framework. Federal ministry of agriculture and rural development, Abuja

Adejuwon SA (2004) Impacts of climate variability and climate change on crop yield in Nigeria. In: Paper presented at the stakeholder's workshop on assessment of impacts and adaptation to climate change, conference centre, Obafemi Awolowo University, Ile-Ife 20-21 September 2004

Adesina FA, Odekunle TO (2011a) Climate change and adaptation in Nigeria: some background to Nigeria's response - part I. 2011. International conference on environmental and agriculture engineering IPCBEE vol.15 (2011). IACSIT Press, Singapore

Adesina FA, Odekunle TO (2011b) Climate change and adaptation in Nigeria: some background to nigeria's response - part III. 2011. International conference on environmental and agriculture engineering IPCBEE vol.15 (2011). IACSIT Press, Singapore

Adger WN, Agrawala S, Mirza MMQ, Conde C, O'Brien K, Pulhin J, Pulwarty R, Smit B, Takahashi K (2007) Assessment of adaptation practices, options, constraints and capacity in climate change 2007: impacts, adaptation, and vulnerability. Contribution of working group II to the fourth assessment report of the intergovernmental panel on climate change. Eze and Osahon; AJAEES 6(1):45-55, 2015; Article no.AJAEES.2015.061 Asian Journal of Agricultural Extension, Economics \& Sociology 6(1):45-55, 2015; Article no.AJAEES.2015.061 ISSN: 2320 7027

Anríquez G, Stamoulis S (2007) Rural development and poverty reduction: is agriculture still the key? Journal of Agricultural and Development Economics 4(1):5-46

Eze S and Osahon E (2015) Indigenous mitigation and adaptation to climate change among small holder farmers in arochukwu area of Abia State, Nigeria. Asian Journal of Agricultural Extension, Economics \& Sociology 6(1): 45-55. Article no. AJAEES.2015.061 ISSN: 23207027

Feenstra JF, Burton I, Smith JB, Tol RS (eds.) (1998) Handbook on Methods for Climate Change Impact Assessment and Adaptation Strategies. United Nations Environment Programme; Vrije Universiteit, Amsterdam. 8-1 - 8-39

Hair JF, Black WC, Babin BJ, Anderson RE (2010) Multivariate data analysis: international version. Pearson, New Jersey 
Intergovernmental Panel on Climate Change- IPCC (2007) Summary for policymakers, in climate change 2007: impacts, adaptation and vulnerability. Contribution of working group II to the fourth assessment report of the intergovernmental panel on climate change. Cambridge University Press, Cambridge, UK, p 17

Lybbert T, Sumner D (2010) Agricultural technologies for climate change mitigation and adaptation in developing countries: policy options for innovation and technology diffusion. International Centre for Trade and Sustainable Development (ICTSD), Geneva

Malhotra NK, Dash S (2011) Marketing research an applied orientation. Pearson Publishing, London

Marrewijk L (2011) Climate smart agriculture in the Mutale Basin, South Africa. Sustain Livelihoods Biodivers Dev Countries 4(2):5-6

Parry ML, Rosenzweig Cynthia, Iglesias Ana, Livermore M, Fischer Günther (2004) Effects of climate change on global food production under SRES emission and socio-economic scenarios. Global Environmental Change 14:53-67. https://doi.org/10.1016/j.gloenvcha.2003.10.008

Ringle CM, Wende S, Will A (2005) SmartPLS 2.0.M3. SmartPLS, Hamburg, https://www. smartpls.com/smartpls2

United States Environmental Protection Agency -USEPA (2014) Climate change impacts and adapting to change. Retrieved March 31, 2015, from http://www.epa.gov/climatechange/ impacts-adaptation/

United States Global Change Research Program -USGCRP (2009) Global climate change impacts in the United States. In: Karl TR, Melillo JM, Peterson TC (eds) United States global change research program. Cambridge University Press, New York

Wisner B, Blaikie P, Cannon T, Davis I (2004) At risk: natural hazards; people's vulnerability and disasters. 2nd Edition. London: Routledge

Open Access This chapter is licensed under the terms of the Creative Commons Attribution 4.0 International License (http://creativecommons.org/licenses/by/4.0/), which permits use, sharing, adaptation, distribution and reproduction in any medium or format, as long as you give appropriate credit to the original author(s) and the source, provide a link to the Creative Commons license and indicate if changes were made.

The images or other third party material in this chapter are included in the chapter's Creative Commons license, unless indicated otherwise in a credit line to the material. If material is not included in the chapter's Creative Commons license and your intended use is not permitted by statutory regulation or exceeds the permitted use, you will need to obtain permission directly from the copyright holder.

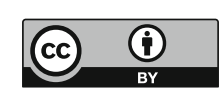

